\title{
GAO Report on Security Force Assistance
}

\author{
More Detailed Planning and Improved Access to Information Needed to \\ Guide Efforts of Advisor Teams in Afghanistan
}

\section{Highlights}

\section{Why GAO Did This Study}

ISAF's mission in Afghanistan has shifted from a combat role to focus more on preparing ANSF units to assume lead security responsibility by the end of 2014. A key element in advising and assisting the ANSF is SFA advisor teams, provided by the U.S. Army and Marine Corps. A House Armed Services Committee report accompanying its version of the Fiscal Year 2013 National Defense Authorization Act directed GAO to review DOD's establishment and use of SFA advisor teams. Specifically, GAO evaluated the extent to which (1) DOD, in conjunction with ISAF, has defined SFA advisor team missions, goals, and objectives; (2) the Army and Marine Corps have been able to provide teams; and (3) the Army and Marine Corps have developed programs to train teams for their specific missions. GAO reviewed doctrine and guidance, analyzed advisor requirements, reviewed training curricula, and interviewed Army, Marine Corps, theater command, and SFA advisor team officials in the U.S. and Afghanistan.

\section{What GAO Recommends}

GAO recommends that theater commanders take steps to work with brigade commanders and advisor teams to identify end states, objectives, and milestones for the development of their ANSF counterpart units in support of the regional commands' broad goals, and that the Army and Marine Corps improve availability of missionspecific information prior to advisor teams' deployment. DOD partially concurred with GAO's recommendations and identified actions to further prepare SFA advisor teams for their missions.

\section{Abbreviations}

ANSF

CENTRIXS-I

COMISAF

DOD

ISAF

SFA
Afghan National Security Forces

Combined Enterprise Regional Information Exchange System-ISAF

Commander, International Security Assistance Force

Department of Defense

International Security Assistance Force

Security Force Assistance

The report under the title "Security Force Assistance: More Detailed Planning and Improved Access to Information Needed to Guide Efforts of Advisor Teams in Afghanistan" (GAO-13381) was presented to the relevant committees in the U.S. Congress by the United States Government Accountability Office in April 2013. The full text of the original report is available at www.gao.gov/products/GAO-13-381. 


\section{Main Findings}

DOD and the International Security Assistance Force (ISAF) have defined the mission and broad goals for Security Force Assistance (SFA) advisor teams; however, teams varied in the extent to which their approaches for developing their Afghan National Security Force (ANSF) units identified activities based on specific objectives or end states that were clearly linked with established goals. SFA guidance states that to be successful, advisors must have an end or goal in mind, and establish objectives that support higher-command plans. Theater commanders have outlined goals aimed at strengthening specific capabilities such as logistics, and it is largely left to the teams to then develop their approach for working with their counterparts. GAO found some advisor teams had developed structured advising approaches drawing from these goals, such as identifying monthly objectives and milestones for their team. Other teams GAO met with used less structured approaches, such as relying on interactions with ANSF counterparts to identify priorities and using this input to develop activities on an ad hoc basis, rather than as part of a longer-term, more structured approach to achieve broad goals. Officials from several teams stated that the guidance they received lacked specificity regarding desired end states for the development of their ANSF counterpart units. Without a more structured approach with clear linkages between end states, objectives, and milestones that are in support of broad goals for ANSF units, theater commanders cannot be assured that the advisor team activities are making progress toward these goals.

The Army and Marine Corps have been able to fill requests for SFA advisor teams, using various approaches such as tasking non-deployed brigades to form advisor teams or creating teams using personnel already deployed in Afghanistan. According to Army and Marine Corps officials, the ability to substitute an individual at one rank above or below the request has helped the services meet rank and skill requirements. The Army's reliance on brigades to provide a portion of their personnel to form advisor teams has enabled them to meet requirements but resulted in leaving large numbers of personnel at the brigades' home stations. To manage these large rear detachments, brigades undertook significant planning to ensure that enough stay-behind leadership existed to maintain a sufficient command structure and provide certain training.

The Army and Marine Corps have developed training programs for SFA advisor teams, but teams varied in the extent to which they had specific information to help prepare them for their mission prior to deployment. SFA guidance states that an indepth understanding of the operational environment and of foreign security force capabilities is critical to planning and conducting effective SFA. Advisor teams may access such information from a variety of sources such as conducting video teleconferences with the teams they will replace, using secure networks to gather information, or sending personnel on predeployment site surveys, although teams varied in the extent to which they were actually able to gain access to these sources. For example, GAO found that while teams had access to a certain secure network at training sites, only some had access at home station, enabling them to shape their training and mission analysis earlier in predeployment training or after training but prior to deploying. 
Having limited access to this information prior to arriving in Afghanistan may result in advisor teams needing more time after deploying to maximize their impact as advisors.

\section{Letter to Committees' Chairs and Ranking Members}

In November 2010, the Afghan government and North Atlantic Treaty Organization (NATO) agreed upon a plan for transferring lead security responsibilities from the NATO-led International Security Assistance Force (ISAF) to the Afghan National Security Forces (ANSF) by the end of 2014 while drawing down international forces. As part of this transition the focus of NATO's mission in Afghanistan is shifting from a combat role to a security force assistance (SFA) role more focused on advising and assisting the ANSF. For the U.S. contribution, the Department of Defense (DOD) has used a variety of approaches to provide U.S. forces to carry out the advise-and-assist mission. For example, in early 2012, the U.S. Army and Marine Corps began to deploy small teams of advisors with specialized capabilities - referred to as SFA advisor teams - that are located throughout Afghanistan to work with Afghan army and police units. Our past work has identified challenges DOD has faced in supporting the advising mission, such as providing and training advisor personnel, balancing advising activities with other missions, and defining command relationships. ${ }^{1}$

The House Armed Services Committee report accompanying its version of the Fiscal Year 2013 National Defense Authorization Act directed us to report on DOD's establishment of SFA advisor teams and the use of these teams to further develop the capabilities of the ANSF. ${ }^{2}$ To address this requirement, this report evaluates the extent to which (1) DOD, in conjunction with ISAF, has defined SFA advisor team missions, goals, and objectives, (2) the Army and Marine Corps have been able to provide SFA advisor teams, and (3) the Army and Marine Corps have developed programs to train SFA advisor teams for their specific missions in Afghanistan.

To address these objectives, we reviewed doctrine, guidance, and key planning documents from NATO, the Army, Marine Corps, and ISAF and U.S. theater commanders pertaining to SFA advisor team missions, goals and objectives, as well as staffing and training of the teams. This documentation included the Army's Field Manual for Security Force Assistance, ${ }^{3}$ the ISAF SFA Concept and Implementation Guidance, requests for forces, ISAF minimum training requirements, and lessons learned from SFA advisor teams. Additionally, we met with officials from relevant organizations in the United States, such as the Office of the Secretary of Defense, Department of the Army, Headquarters Marine Corps, U.S. Central Command, Army Forces Command, and Army and Marine Corps training organizations, as well as officials

GAO, Iraq and Afghanistan: Actions Needed to Enhance the Ability of Army Brigades to Support the Advising Mission (Washington, D.C.: GAO, August 2011), Available at www.gao.gov/products/GAO-11-760.

2 H.R. Rep. No-112-479, at 263-264 (2012) accompanying H.R. 4310. H.R. 4310 became Public Law No. 112-239.

3 Department of the Army, Army Field Manual 3-07.1, Security Force Assistance (May 2009). 
from organizations in Afghanistan, including U.S. Forces-Afghanistan, ISAF, division and brigade headquarters, and 23 SFA advisor teams. Although many ISAF coalition countries deploy SFA advisor teams, the scope of this review included only U.S. SFA advisor teams.

We conducted this performance audit from June 2012 to April 2013 in accordance with generally accepted government auditing standards. Those standards require that we plan and perform the audit to obtain sufficient, appropriate evidence to provide a reasonable basis for our findings and conclusions based on our audit objectives. We believe that the evidence obtained provides a reasonable basis for our findings and conclusions based on our audit objectives. Appendix I contains additional information about our scope and methodology.

\section{Background}

Since 2001, the United States and its NATO partners have been responsible for securing Afghanistan and leading the effort to secure, stabilize, and rebuild Afghanistan. In 2010, the United States, NATO, and other coalition partners agreed to transition lead security responsibility for Afghanistan from NATO to the Afghan government by the end of 2014. Specifically, the Afghan government and ISAF-including the United States-agreed to a transition process that emphasizes a shift in ISAF's role from leading combat missions to advising and assisting the ANSF, resulting in ISAF shifting to a security force assistance mission. ${ }^{4}$ Lead security responsibility in Afghanistan is defined as responsibility and accountability for planning and conducting operations within a designated area, with ISAF support as required. At the same time, overall U.S. force levels are planned to draw down over the next year to about 34,000 with additional decisions on drawdown of remaining U.S. forces yet to be determined.

ISAF is a NATO-led mission in Afghanistan established by the United Nations Security Council in December 2001. The ISAF coalition currently consists of 28 NATO nations, including the United States, and 22 partnering nations with forces deployed across Afghanistan. ISAF is divided into six regional commands across Afghanistan, each with a specific geographic area of responsibility-North, East, South, Southwest, West, and the Kabul area (known as Regional Command-Capital). The United States leads three of these commands-East, South, and Southwest.

In addition to conducting security operations, ISAF forces have long been training and advising the ANSF both in training centers and at unit locations after they have been formed and fielded. For the U.S. contribution, DOD has used a variety of approaches to provide U.S. forces to carry out the advise-and-assist mission. For example, prior to 2010, the advising mission in Afghanistan was primarily conducted with transition teams. These teams did not exist as units in any of the services' force struc-

4 Army doctrine defines SFA as the unified action to generate, employ and sustain local, host nation or regional security forces in support of a legitimate authority. According to NATO, in Afghanistan SFA encompasses all ISAF actions to develop ANSF operational effectiveness and includes partnering and advising, as well as provision of support to ANSF units. 
tures and were instead comprised of company- and field-grade officers and senior noncommissioned officers who were centrally identified and individually selected based on rank and specialty. ${ }^{5}$ As we have previously reported, the demand for these leaders created challenges for the services because, among other things, the leaders were generally pulled from other units or commands, which then were left to perform their missions while understaffed. ${ }^{6}$ In part as a means of alleviating these challenges, the Army developed the concept of augmenting brigade combat teams with specialized personnel to execute the advising mission, and began deploying these augmented brigades in 2010. In early 2012, based on requests from ISAF as part of its shift to a security force assistance mission, the U.S. Army and Marine Corps began to deploy small teams of advisors with specialized capabilities, referred to as SFA advisor teams, which are located throughout Afghanistan, to work with Afghan army and police units from the headquarters to the battalion level, and advise them in areas such as command and control, intelligence, and logistics. ${ }^{7}$ More recently, the Army began tailoring the composition and mission of its brigade combat teams to further focus on advising efforts.

U.S. advisor teams are under the command and control of U.S. commanders within ISAF's regional commands. ${ }^{8}$ The regional commands have overall responsibility for operations in their geographic area, including setting goals for the advising mission. ISAF establishes the requirements for advisor teams, including force needs, and training requirements. To meet the U.S. share of these requirements, the Army and Marine Corps are responsible for providing advisor personnel, establishing service-specific training requirements, and conducting training prior to deployment.

\section{SFA Advisor Team Mission and Goals Are Broadly Defined; Advisor Teams Varied in the Extent to Which Their Approaches Identified Specific Objectives and Activities Linked to Goals}

DOD and ISAF have defined the mission and broad goals for advisor teams based on the type of ANSF (e.g., army, police) and the type of unit, from the headquarters to the

5 Company-grade officers are those in the pay grades of O-1 to O-3 (e.g., lieutenants and captains) and field-grade officers are those in pay grades O-4 to O-6 (e.g., majors, lieutenant colonels, colonels). Senior non-commissioned officers are those in the pay grades of E7 to E9 (e.g., sergeants first class, first sergeants, sergeants major).

6 GAO-11-760, available at www.gao.gov/products/GAO-11-760 and GAO, Iraq and Afghanistan: Availability of Forces, Equipment, and Infrastructure Should Be Considered in Developing U.S. Strategy and Plans, GAO-09-380T (Washington, D.C.: GAO, February 2009), available at www.gao.gov/products/GAO-09-380T.

7 The U.S. Army and Marine Corps have provided the majority of U.S. advisor personnel to Afghanistan, and the Navy and Air Force also have contributed personnel to advise the ANSF.

8 There are some limited instances where U.S. advisor teams may be operating in regional commands that are not led by the United States, though these teams remain under U.S. command. 


\section{THE QUARTERLY JOURNAL}

battalion level. Advisor teams varied in the extent to which their approaches for developing their ANSF counterparts identified activities based on specific end states, objectives, and milestones that are in support of the regional command's broad goals.

\section{DOD and ISAF Have Defined the Mission and Broad Goals for Advisor} Teams for Various Types of ANSF Units

The mission for advisor teams for various types of ANSF units are defined in multiple ISAF and DOD plans, directives, and orders. According to DOD documentation, SFA advisor teams provide training, advising, assisting, and development functions to prepare ANSF units to assume full security responsibility by December 31, 2014. Missions also have been defined for SFA advisor teams based on the type of ANSF unit they advise, specifically:

- Afghan National Army advisor teams are expected to advise and assist those units, act as liaisons to ISAF units, and support the operational planning and employment of the Afghan unit as part of helping to develop a self-sufficient, competent, and professional unit capable of autonomous operations.

- Afghan National Police advisor teams are expected to advise those units, act as liaisons to ISAF units, and support the operational planning and employment of the Afghan unit as part of helping to develop a self-sufficient, competent and professional unit capable of maintaining public order, security, and rule of law.

- Operational Coordination Center advisor teams are expected to advise those units, act as liaisons to ISAF units and support the development of a coherent security coordination structure. ${ }^{9}$

The regional commands have amplified this guidance for advisor teams by providing key advising goals based on the developmental needs of the ANSF in their region. For example, Regional Command-South identified their top-five advising goals, aimed at strengthening ANSF capabilities such as logistics, countering improvised explosive devices, and medical evacuation. Regional Command-East had a similar set of top-five advising goals.

\section{Advisor Teams Varied in the Extent to Which Their Approaches Identified Activities Based on Specific Objectives Linked to ANSF Development Goals}

While ISAF and the regional commands have defined the mission and broad goals for the advisor teams, it is largely left to the teams, in coordination with the regional command and brigade commander for their area of operations, to develop their approach for working with their ANSF counterpart units. According to multi-service guidance on advising, in order to successfully exert influence, advisors have an end or goal in

9 Operational Coordination Centers are ANSF command-and-control organizations that coordinate security operations and civil response to developing situations in their respective areas of responsibility. 
mind. ${ }^{10}$ Similarly, the Army's Field Manual for Security Force Assistance states that, in order to be successful, advisors have an end or goal in mind and should establish objectives and milestones that support higher-command plans and can be achieved during their deployment. ${ }^{11}$ In addition, advisor teams must balance the priorities of their commands with those of their counterpart units. Specifically, DOD officials emphasized that advisor teams need some flexibility to tailor their approaches to the respective needs of their ANSF counterpart units while still working towards regional command goals. Advisor teams we spoke with were generally familiar with the broad goals established by ISAF and regional commands, but used various approaches to develop their ANSF counterpart units, which varied in the extent to which they resulted in the identification of activities based on specific objectives or end states that were clearly linked with established goals.

Some teams we spoke with had taken the initiative to develop structured approaches that identified objectives or end states and milestones, drawing from the regional command's broader goals to guide their advising efforts. For example, one team stated they worked directly from the regional commander's top-five goals, developing a planning process to identify monthly objectives and milestones for each advising area (e.g., personnel, intelligence, logistics) that support these goals, and then regularly assessing where they are in terms of progress towards the commander's goals and in what areas they should continue to focus. Using this process, the advisor team identified a training need for an ANSF brigade related to the regional commander's broad goal of developing the ANSF's counter improvised explosive device capabilities and arranged for a U.S. Explosive Ordinance Disposal unit to provide this training. In another instance, a logistics advisor team identified a need for its ANSF counterpart to be capable of repairing items such as cranes and fuel distribution equipment to help achieve the regional command's broad goal of developing general level maintenance capability. To achieve this objective, the team created a training program to develop this capability. Another team leader we spoke with stated he developed advising plans based on the regional command's high level goals and informed by an assessment of their ANSF counterpart unit, to identify tasks and timelines to train their counterparts on basic skills such as map reading in order to improve their ability to plan and conduct operations.

Other advisor teams we met with were familiar with the broad goals for ANSF development and had identified activities to develop their ANSF counterpart units, but used less structured approaches to guide their advising efforts. For example, advisor teams in multiple regional commands stated their approach was to rely on interactions with their ANSF counterparts to identify priorities, using this input to develop activities on an ad hoc basis. Similarly, according to a brigade commander serving as an advisor team leader, his team and other advisor teams from his brigade generally identi-

\footnotetext{
10 Department of the Army, Army Field Manual 3-07.10, Advising: Multi-service Tactics, Techniques, and Procedures for Advising Foreign Forces (September 2009). This guidance applies to the Army, Marine Corps, Navy, and Air Force.

11 Army Field Manual 3-07.1, Security Force Assistance (May 2009).
} 
fied development activities in reaction to situations as they arose rather than as part of a longer-term, more structured approach to achieve broad goals. According to several advisor teams, while they received input from various higher headquarters, that input lacked specificity regarding end states they should be trying to achieve for their ANSF units, leading them to use less structured approaches to guide their efforts. For example, the deputy team leader of an advisor team for a high-level Afghan National Army unit with visibility over the efforts of several advisor teams for subordinate ANSF units stated that while his team was able to develop activities intended to enable his counterpart unit to operate independently, he believed that guidance from the regional command did not clearly define the overall desired end state for the ANSF, which made it difficult to determine where to focus their particular advising efforts. Similarly, officials responsible for collecting best practices and lessons learned from SFA advisor teams in one regional command said that, in talking with teams, they found a lack of direction for advisor teams from higher headquarters resulted in what they characterized as a collection of good activities conducted by individual teams over time without a synchronized approach driving towards a tangible end state. Without a more structured approach with clear linkages between objectives or end states linked to development goals for ANSF units, regional commanders cannot be assured that the activities of individual advisor teams are in fact making progress toward established goals. Moreover, having such an approach would help with continuity of effort from one advisor team to the next, since advisor teams typically deploy for 9 months.

\section{The Army and Marine Corps Have Provided the Required Number of SFA Advisor Teams While Managing Ongoing Challenges}

The Army and Marine Corps have provided the required number of SFA advisor teams to Afghanistan based on theater commanders' requests. Recognizing that high ranks and skill specialties were required for advisor teams, theater commander guidance allowed for some substitutions when specific ranks or skills were unavailable, which enabled the Army and Marine Corps to provide the appropriate personnel. The Army's use of brigades to form advisor teams has enabled them to meet requirements but has resulted in leaving large numbers of brigade personnel at their home station locations. To manage these large rear detachments, brigade leadership undertook significant planning to ensure enough stay-behind leadership existed to maintain a sufficient command structure and provide certain training and exercises.

\section{The Army and Marine Corps Have Provided the Required Number of SFA Advisor Teams Based on Theater Commanders' Requests}

In late 2011, ISAF and U.S. Forces-Afghanistan established requirements for coalition and U.S. SFA advisor teams, including specifying the number of teams required, team composition and capabilities, and assignment to ANSF units. Although the numbers of teams have changed over time, according to ISAF, the Army and Marine Corps have provided the required number of SFA advisor teams based on these requests and, as of December 2012, approximately 250 U.S. advisor teams were operating in Afghanistan. 
SFA advisor teams are generally comprised of 9 to 18 advisor personnel — made up of a mix of company- and field-grade officers, and senior non-commissioned officerswith specific specialties such as military intelligence, military police, and signal officers. The composition of advisor teams is tailored to match the needs of their ANSF counterpart. For example, teams at higher echelons of the ANSF (e.g., corps or provincial headquarters) have a higher rank requirement for the advisor team leader and police advisor teams include requirements for military police personnel. According to ISAF, Army, and Marine Corps officials, advisor teams are generally expected to remain with the same ANSF unit for the duration of their approximately 9-month deployments. According to DOD and ISAF officials, the requirement for advisor teams has fluctuated as additional ANSF units have been fielded, and the overall requirement for advisor teams is expected to change as the development of ANSF units progresses. For example, according to ISAF officials, SFA advisor teams currently advise down to the battalion level, but as U.S. forces draw down in Afghanistan and the capability of the ANSF increases, the U.S. advising effort could shift to a brigade-and-higher focus, which could affect the overall number and size of the teams.

U.S. SFA advisor teams began deploying to Afghanistan in early 2012, and the Army and Marine Corps have used a variety of approaches to provide these teams:

- To meet its requirements for the first set of advisor team deployments, the Army tasked three non-deployed brigades to form the bulk of the advisor teams using personnel from their units, with additional non-deployed units tasked to form the remaining teams. These advisor teams then deployed to Afghanistan and were attached to combat brigades already in theater. More recently, the Army shifted its sourcing approach by tailoring the composition and mission of brigades deploying to Afghanistan to further focus on the SFA mission, and began deploying these SFA brigades (SFABs) in November 2012. According to ISAF officials, SFABs include advisor teams that are primarily created using personnel from within the brigade. According to Army officials, as of January 2013, three SFABs have deployed in place of combat brigades, and at least four more U.S. brigades in Afghanistan have been identified to be replaced by SFABs. According to Army officials, the Army will continue to provide some advisor teams using personnel from non-deployed active and reserve units that will join the remaining combat brigades in Afghanistan. Additionally, planning for the remaining brigades and overall force levels in Afghanistan is ongoing and by late 2013 all deploying U.S. brigades may be SFABs.

- To meet the initial deployment of SFA advisor teams beginning in early 2012, the Marine Corps created some teams out of personnel already deployed in Afghanistan and created additional teams using non-deployed personnel generally from the I and II Marine Expeditionary Forces, according to Marine Corps officials. For subsequent deployments of teams, the Marine Corps has created teams using non-deployed personnel from across the Marine Expeditionary Forces that then deploy to Afghanistan as formed teams. 


\section{The Army and Marine Corps Used Substitution Allowances and Individual Augmentees to Address Challenges in Meeting Rank and Skill Requirements}

The Army and Marine Corps have been able to fill SFA advisor teams, but they continue to face challenges meeting specific rank and skill requirements. In 2011, we reported on challenges the Army was experiencing providing high-ranking personnel with specialized skills for the advising mission in Afghanistan. ${ }^{12}$ According to Army and Marine Corps officials, meeting the rank and skills required for SFA advisor teams, including those as part of SFABs, continues to present a challenge given the limited availability of such personnel across the services. To help address these challenges, theater commanders, in coordination with the Army and Marine Corps, have outlined a set of substitution guidelines, to allow flexibility in the rank and skill requirements. For instance, specific rank requirements can generally be substituted with an individual one rank above or below the requirement. Similarly, there are guidelines for different skills and specialties that may be substituted for one another. For example, a team may have a requirement for a specific type of intelligence officer, but the substitution guidance identified other types of intelligence personnel that could be used to meet this requirement such as a counterintelligence or signals intelligence analyst. Army Forces Command officials told us that because the required number of ranks and specialties for SFA advisor teams exceeds the total number of such personnel that exist in a typical brigade, the ability to substitute certain ranks and skills with other available personnel was critical to meeting the requirement for most advisor teams and for all three of the first deploying SFABs. Army officials recognized that substitutions would need to occur both within and among brigades. According to sourcing officials and officials from one of the brigades tasked to provide the first set of advisor teams, the following are examples:

- While 40 majors were required to fill the specified number of teams, the brigade had only 25 majors on hand. Recognizing this, the Army's plan called for substituting captains for majors in order to meet the requirement.

- The requirement for certain intelligence officers exceeded that which existed in the brigade. Therefore, brigade leadership used lower ranking military intelligence officers or other officers with sufficient related experience.

According to Army officials, the rank and skill requirements, as well as the reliance on substitutions, are expected to continue with the use of SFABs. As the Army and Marine Corps began to form the teams, they also worked with their force providers in order to utilize individual augmentees from active and reserve non-deployed units to help meet the rank and skill requirements for SFA advisor teams. For example, an official from a Marine Expeditionary Force responsible for providing many of the first advisor teams stated that the unit used reservists to fill over 130 advisor slots, and the Marine Corps expects to continue to use them to fill subsequent teams.

12 GAO-11-760, available at www.gao.gov/products/GAO-11-760. 


\section{The Army Is Taking Steps to Manage Large Rear Detachments That Result from SFA Advisor Team Sourcing Approaches}

The Army's sourcing approaches enabled it to meet theater requirements for SFA advisor teams, but resulted in brigades leaving large numbers of personnel at home station locations. For the first set of Army deployments, the three brigades identified to source the bulk of the teams left the majority of their personnel at home station. For example, according to brigade officials, one brigade deployed approximately 370 people to create advisor teams, leaving approximately 3,100 personnel (approximately 90 percent) behind at home station. According to Army officials, SFABs reduce the size of the rear detachments because a larger percentage of the brigade's personnel are to be deployed, although they recognized SFABs would continue to result in large rear detachments. For example, two of the first SFABs to deploy each left roughly 2,000 personnel at home station. Because the advisor team requirement calls for high numbers of company- and field-grade officers and senior non-commissioned officers, as well as specific skill specialties, staffing the teams required the brigades to deploy a significant portion of their leadership and expertise, including the brigade commanders and many battalion, company, and platoon commanders, for the advisor mission. As a result, according to Army Forces Command officials and officials from two brigades, brigade leadership had to undertake significant planning to ensure that enough stay-behind leadership existed to maintain a sufficient command structure and the unit leadership needed to conduct certain training, such as artillery and other live-fire exercises. In order to help brigades in this planning, Army Forces Command has issued guidance for the training and employment of rear detachments during advisor team deployments, including missions the force may be assigned to, training expectations, and equipment maintenance responsibilities. For example, one brigade that deployed many of the first set of advisor teams consolidated its rear detachment into smaller numbers of more fully manned platoons to ensure appropriate leadership existed for each platoon. In addition, the brigade leadership developed a training plan for the rear detachment to maintain proficiency in critical tasks while awaiting reintegration of deployed personnel.

\section{The Army and Marine Corps Have Developed Programs to Train Advisor Teams, but Teams Differed in the Extent to Which They Had Mission-Specific Information Prior to Deployment}

The Army and Marine Corps have developed standardized predeployment training programs for SFA advisor teams in Afghanistan, but teams varied in the extent to which they had access to mission-specific information prior to deploying that they believed would help them prepare for their specific advising missions.

\section{The Army and Marine Corps Have Developed Predeployment Training Programs for SFA Advisor Teams}

SFA advisor teams take part in a broad set of training activities both at home station and at training centers in the months leading up to their deployment. ISAF has estab- 
lished minimum training requirements for SFA advisor teams from all coalition countries, including the United States. These training requirements include both individual advisor knowledge and skills, such as understanding how to work through an interpreter, and collective team knowledge and skills, such as how the advisor team will assess ANSF unit capabilities and provide force protection and sustainment. ISAF envisions that this training will be conducted using a combination of individual and teambased training. In accordance with these requirements, the Army and Marine Corps have each developed a program of instruction for predeployment training, which generally occurs in three stages:

- Home-Station Training. Home-station training includes individual and teamlevel combat skills training provided to all deploying forces to Afghanistan. Typically, SFA advisor teams are formed prior to the beginning of this training. Topics include combat lifesaver training, various weapons and driving qualifications, and countering improvised explosive devices. During this period, teams also begin to gather information regarding their specific advising assignment in order to conduct mission analysis, shape the next two stages of their training, and establish their initial plan for their advising missions. ${ }^{13}$ For example, officials at the Joint Readiness Training Center Operations Group, which conducts culminating training exercises for Army advisor teams and SFABs, told us that it is during this time that they begin to work with commanders to design their culminating training exercise.

- Advisor-Specific Training. Advisor-specific training is focused on language, culture, counterinsurgency, and advisor skills. Army advisor teams generally receive advisor-specific training during an 8-day course provided by the $162^{\text {nd }}$ Infantry Training Brigade. ${ }^{14}$ Marine Corps teams receive training at the Advisor Training Cells at their respective Marine Expeditionary Force home stations, as well as the Advisor Training Group at the Marine Corps Air Ground Combat Center. ${ }^{15}$ Both the Army and Marine Corps training includes courses such as overviews of Afghan security force institutions, how to use an interpreter, and techniques for building rapport. The training also utilizes role

13 Mission analysis is used to study the assigned tasks and to identify all other tasks necessary to accomplish the mission. According to Joint Publication 5-0 Joint Operation Planning, mission analysis is critical because it provides direction to the commander and the staff, enabling them to focus effectively on the problem at hand.

14 Army officials told us that some advisor personnel receive an 8 -week course from the $162^{\text {nd }}$ Infantry Training Brigade, which includes both combat skills training and advisor-specific training and is based on a variety of factors including the training capabilities of home units.

15 Advisor training cells are training sites located at each Marine Expeditionary Force home station, which provide training capabilities for advisor teams that work with foreign security forces, including SFA advisor teams in Afghanistan. The Advisor Training Group is located at the Marine Corps Air Ground Combat Center in Twentynine Palms, California, and its purpose is to train Marine Corps teams that advise, mentor, and train foreign military, police, and border units in operational techniques and procedures. 
players in practical exercises to simulate engagements with key Afghan civilian and military leaders in different situations.

- Culminating Training Exercise. This training includes situational training exercises and a culminating training exercise that integrates ANSF role players into a simulated deployed environment in order to exercise the advisor teams' ability to advise their ANSF counterpart units. For Army advisor teams, this exercise is incorporated into the culminating training exercise of the brigade under which they will operate in Afghanistan, when possible, and is conducted at the Joint Readiness Training Center at Fort Polk, Louisiana, or other combat training centers. These exercises include training based on the level (e.g., brigade, battalion) and type (e.g., army, police) of the ANSF unit that teams will be advising and their specific areas of responsibility in Afghanistan, individual and team proficiency assessments, and live-fire drills, such as combat patrols. Marine Corps advisor teams receive similar training at the Advisor Training Group, though this training does not include the combat unit with which they will be operating in Afghanistan.

The Army, Marine Corps, and ISAF have established mechanisms to gather feedback on predeployment training from advisor teams in Afghanistan in order to update and refine training for the advisor mission. Both the Army and Marine Corps centers for lessons learned have ongoing efforts in Afghanistan to collect observations and best practices for SFA advisor teams. Additionally, the 162nd Infantry Training Brigade employs liaison officers at ISAF and the regional commands, among other places, to collect lessons learned and after-action reports from advisor teams in Afghanistan, which are then incorporated into advisor training. Officials from the 162nd Infantry Training Brigade said that, based in part on this feedback, the advisor training has changed significantly since the first SFA advisor teams began going through the training in January 2012, and that the program of instruction will continue to evolve. For example, officials from two of the first SFA advisor teams told us that the advisor training was too focused on classroom instruction. Officials from the $162^{\text {nd }}$ Infantry Training Brigade said that they had heard similar concerns, and later iterations of SFA advisor team training was updated to provide greater balance between classroom training and practical exercises that use cultural role players. Further, between August 2012 and October 2012, ISAF conducted a survey of U.S. and coalition nation SFA advisor team personnel on predeployment training in order to provide advisor insights to U.S. and NATO training centers and made several recommendations to improve predeployment training. For example, ISAF recommended that advisor teams contact the unit they will be replacing to fine tune their training in order to meet the challenges they will face upon deployment.

\section{Advisor Teams Varied in the Extent to Which They Had Access to Information to Help Prepare for Their Specific Advising Missions Prior to Deployment}

ISAF's minimum training requirements direct advisor teams to conduct mission analysis prior to deployment in order to develop plans for advising their ANSF counterpart 
unit. Further, the Army's Field Manual for Security Force Assistance, states that an indepth understanding of the operational environment - including a clear understanding of the theater, population, and the foreign security forces and capabilities with which they are working - is critical to planning and conducting effective SFA. ${ }^{16}$ According to some advisor team officials and ISAF officials tasked with gathering lessons learned from advisor teams and identifying potential challenges, the personalities and capabilities of each ANSF unit and district are unique, and advisor teams need specific information on their ANSF counterpart unit as well as the efforts of the advisor teams currently working with the unit prior to deployment in order to be successful. In addition, some advisors stated that having specific information about the operational environment where teams will be deployed would be beneficial in determining where to place emphasis during training. For example, some advisor teams we spoke with are able to walk to their counterpart unit's headquarters, while other teams had to travel longer distances to accompany their counterpart units. Having this type of specific information about their operating environment could be helpful for advisor teams in tailoring some of their more general combat training at home station.

Advisor teams varied in the extent to which they had access to information to help prepare for their specific advising missions prior to deployment. Advisor teams may gain access to this information through a variety of ways. For example, officials from the 162nd Infantry Training Brigade said that they coordinate video teleconferences between advisor teams going through advisor training and deployed advisor teams with the goal that advisor teams are able to talk to the SFA advisor team that they will replace to help the deploying team better understand its specific mission and the unit that it will be advising. Advisor teams can also utilize secure networks to gather missionspecific information. For example, much of the information on advising and general operations in Afghanistan (e.g., daily and weekly update briefs, details of the advisor teams' interactions with ANSF units, and regional command campaign plans) is stored and shared on the Combined Enterprise Regional Information Exchange System-ISAF (CENTRIXS-I) network - a network that is widely used by U.S. and coalition forces in Afghanistan, but with limited access in the United States. Additionally, advisor teams may take part in predeployment site surveys in which commanders take staff members to theater and meet with the units they will be replacing to learn more about the mission they will support. According to the Army Field Manual for Security Force Assistance, the predeployment site survey should, among other things, provide information on the organization, leadership, and capabilities of the foreign unit that will be advised, as well as an overview of the operational area. ${ }^{17}$ ISAF minimum training requirements also require that advisor teams conduct predeployment site surveys as part of their SFA mission analysis and planning.

16 Army Field Manual 3-07.1, Security Force Assistance (May 2009).

17 Army Field Manual 3-07.1, Security Force Assistance (May 2009). 
We found differences in the extent to which advisor teams were actually able to gain access to mission-specific information throughout their predeployment training. For example,

- While some SFA advisor teams told us that mission-specific information shared on CENTRIXS-I is beneficial in shaping their predeployment training and mission analysis, we found that advisor teams varied in the extent to which they were able to access this system and thus the information contained therein throughout their predeployment training. Some advisor teams had access to CENTRIXS-I at home station. For example, officials from one brigade that provided SFA advisor teams said that they recognized the value of CENTRIXS-I in gathering specific information from units on the ground in order for teams to conduct their mission analysis and early planning, and proactively took steps to gain access to the network at home station early on in predeployment training, and were able to obtain access for its SFA advisor teams 5 months prior to deploying. However, other advisor teams said that they had limited or no access to this network at their home stations, thus limiting the information available to the teams to shape training, conduct mission research, and develop situational awareness before arriving in Afghanistan. Advisor teams are able to access CENTRIXS-I once they arrive at the 162nd Infantry Training Brigade and the Advisor Training Group training sites. However, teams are at these locations for a short time (i.e., less than 30 days) in the midto-late stages of training. Advisor teams with limited or no access to CENTRIXS-I at home station may be unable to fully leverage mission-specific information to (1) either shape their training prior to going to these locations or (2) continue to fully maximize the up-to-date information contained therein to prepare for their missions after they leave the training sites.

- Advisor teams varied in their ability to send representatives on predeployment site surveys to Afghanistan. Unit commanders and theater commands determine the numbers of personnel that take part in the survey, taking into consideration limitations on the ability of certain locations to provide transportation, housing, and other support. According to an ISAF official, units tasked with the advising mission are encouraged to take some representatives from their advisor teams on these surveys. According to a U.S. Forces-Afghanistan official, there has been at least one recent case where a predeployment site survey team sent to Afghanistan was augmented with additional personnel in order to accommodate the need to visit multiple locations. In contrast, some advisor teams we spoke with said that they did not send representatives from their individual teams on these site surveys, which limited their ability to shape their training and their understanding of the environment in which they would be operating. For example, one advisor team said that it did not know the specifics of the operating environment when conducting home station training, such as details about security and movement, and that the opportunity to conduct a predeployment site survey would have been helpful for the team's mis- 
sion preparation. Another unit that was organized into three advisor teams reported that they did not take part in a predeployment site survey and thus faced significant challenges during their first 45 days of deployment because they were unaware that logistic support arrangements for the teams in Afghanistan had not been established.

DOD officials acknowledged that increased information prior to deployment would benefit advisor teams, but added that resource constraints are a consideration in determining how to expand access to certain information sources. Nonetheless, without a more complete understanding of the capabilities of the ANSF counterpart units to be advised and the operating environment in which they will be advising prior to deploying, it may take advisor teams more time after deploying to maximize their impact as advisors.

\section{Conclusions}

The use of SFA advisor teams to develop and support the ANSF are a key element of the U.S. and ISAF strategy to transition lead security responsibility to Afghanistan while drawing down combat forces. By ensuring that SFA advisor teams have structured approaches with clear linkages between end states, objectives, and milestones that are in support of broad goals for ANSF units, theater commanders can enhance the ability of advisor teams to develop their ANSF counterparts. In addition, this will enable theater commanders to better gauge an ANSF unit's progress towards their broader development goals and facilitate continuity of effort from one advisor team to the next. Lastly, by improving the availability of mission-specific information prior to deployment, the Army and the Marine Corps will ensure that SFA advisor team have the information necessary on their specific ANSF counterpart and the operational environment to better inform training. Moreover, such information would enhance the ability of advisor teams to prepare for and undertake their efforts immediately upon deployment.

\section{Recommendations for Executive Action}

To ensure that the activities of individual advisor teams are more clearly linked to ISAF and regional command goals for overall ANSF development, we recommend that the Secretary of Defense, in consultation with the commander of U.S. Central Command, direct theater commanders in Afghanistan to work with brigade commanders and advisor teams to identify specific end states, objectives and milestones for developing their ANSF counterparts that are in support of the broad theater goals to guide their advising efforts during their deployment.

To enhance the ability of SFA advisor teams to prepare for and execute their mission, we recommend that the Secretary of the Army and the Commandant of the Marine Corps take steps to improve the availability of mission-specific information during predeployment training. Such steps could include:

- Expanded access to the data and information contained in CENTRIXS-I; and, 
- Increased opportunities, in coordination with U.S. Central Command, for advisor team leaders to participate in predeployment site surveys with the teams they are expected to replace.

\section{Agency Comments and Our Evaluation}

In written comments on a draft of this report, DOD partially concurred with our recommendations. DOD also provided technical comments, which we incorporated where appropriate.

In its comments, DOD partially concurred with our first recommendation that the Secretary of Defense, in consultation with the commander of U.S. Central Command, direct theater commanders in Afghanistan to work with brigade commanders and advisor teams to identify specific end states, objectives, and milestones for developing their ANSF counterparts that are in support of the broad theater goals to guide their advising efforts during their deployment. Also, DOD provided comments regarding the command relationships and guidance affecting the advisor teams. Specifically, DOD stated that the issue of linking advisor teams with regional commanders and the theater commander to identify specific end states, objectives, and milestones resides within the operational level and not at the strategic level with the Secretary of Defense and U.S. Central Command. The department further stated that the Commander, International Security Assistance Force (COMISAF), is the theater commander and produces the operation plans for Afghanistan, which provide the end states, objectives, and milestones for the campaign, including efforts to develop the ANSF and ministerial-level agencies. COMISAF also issues guidance for developing the ANSF and ministerial agencies to include end states, objectives, and milestones. Further, DOD noted that regional commanders receive their guidance and direction in part through the OPLANs and other guidance issued by COMISAF. The department also stated that brigade commanders, SFABs, and SFA advisor teams are operationally and/or tactically controlled by the regional commanders. DOD stated that guidance from the regional commanders for these subordinate elements should include the guidance provided by $\mathrm{CO}$ MISAF regarding development of the ANSF. Lastly, DOD stated that individual ANSF elements advised by SFA advisor teams and SFABs have different levels of capabilities and unique circumstances involved in developing those capabilities. Therefore, DOD stated that commanders at the operational and tactical level should have sole responsibility for directing the development of the individual ANSF elements.

We agree that it is the responsibility of commanders, particularly regional commanders, at the operational and tactical level, to direct SFA advisor teams to develop individual ANSF elements. As we noted in our report, regional commands have overall responsibility for operations in their geographic area, including setting goals for the advising mission. We further noted that the missions for advisor teams are defined in multiple ISAF and DOD plans, directives, and orders and that the regional commands amplify this guidance by providing key advising goals based on the developmental needs of the ANSF in each region. However, we found that it is largely left to advisor teams to develop their approach for working with their ANSF counterpart units and 
that advisor teams varied in the extent to which their approaches identified activities based upon specific objectives linked to ANSF development goals. Therefore, we recommended that theater commanders in Afghanistan should work with brigade commanders and advisor teams to identify specific end states, objectives and milestones for developing their ANSF counterparts that are in support of the broad theater goals to guide their advising efforts during their deployment. We agree with the department's view that directing the development of the individual ANSF elements should be the sole responsibility of commanders at the operational and tactical level. We believe that our recommendation does not conflict with this principle but rather calls for the Secretary of Defense, in consultation with the Commander of U.S. Central Command, to direct the operational commander to ensure that these actions are taken.

Regarding our second recommendation, we recommended that the Secretary of the Army and the Commandant of the Marine Corps take steps to improve the availability of mission-specific information during predeployment training, and provided two examples of such steps for illustrative purposes. DOD commented separately on these examples. Specifically, with respect to the step calling for expanded access to the data and information contained in CENTRIXS-I, DOD concurred and noted that actions had been taken to install CENTRIXS-I kiosks at U.S bases and overseas locations and plans were underway to install additional kiosks. Also, DOD noted that while CENTRIXS-I is a specific capability, it appears that the intent of our recommendation is to expand information flow by any means available, and DOD suggested that we rephrase the first step to read: "Expand access to secure networks in order to gather data and information." We agree that the intent of our recommendation is to expand information flow and to recognize, as noted in our report, that other information sources exist beyond CENTRIXS-I. Based on our discussions with command and advisor team personnel, CENTRIXS-I was cited as an important information source and therefore we cited it as an example in our report. We believe that, as currently worded, our recommendation provides flexibility for the department to determine a range of options for improving the availability of information to advisor teams.

With respect to the step calling for increased opportunities for advisor team leaders to participate in predeployment site surveys, DOD partially concurred. The department stated that advisor teams and the leadership of brigades must collaborate and use the site survey as well as the brigade's intelligence infrastructure to support the teams in getting situational awareness. Further, DOD further noted that space and logistical constraints may limit participation in a brigade's site survey. Given the critical nature of the SFA advisor team mission, DOD noted that team leaders should be given priority to participate in a predeployment site survey, but that a balance must be met regarding the comprehensive nature of the mission in Afghanistan. Additionally, the department stated that while the Secretary of the Army and the Commandant of the Marine Corps can explore timing opportunities for advisor team leaders to participate in predeployment site surveys, the Afghanistan theater of operations has responsibility for ultimate approval for a site-survey visit request. As a result, the department recommended that we rephrase the second step to include the wording "in coordination with U.S. Central Command." We agree that various factors can affect the composition 
of the personnel participating in the site surveys and that the theater of operations has responsibility to approve visit requests. Our report specifically notes that unit commanders and theater commands determine the numbers of personnel that take part in the predeployment site survey, and take into consideration limitations on the ability of certain locations to provide transportation, housing, and other support. Based on DOD's comments, we modified the text of our second step as DOD suggested.

We are sending copies of this report to the appropriate congressional committees. We are also sending copies to the Secretary of Defense; the Chairman of the Joint Chiefs of Staff; the Secretary of the Army; the Commandant of the Marine Corps; and the Commander of U.S. Central Command. In addition, the report will also be available on our website at http://www.gao.gov.

If you or your staff have questions about this report, please contact me at (202) 512-9619 or pickups@gao.gov. Key contributors to this report are listed in appendix III.

Sharon L. Pickup, Director, Defense Capabilities and Management

\section{Appendix I: Scope and Methodology}

To determine the extent to which the Department of Defense (DOD), in conjunction with the International Security Assistance Force (ISAF), has defined Security Force Assistance (SFA) advisor team missions, goals, and objectives, we reviewed doctrine and guidance from the Army, Marine Corps, and theater commanders, including the Army Field Manual 3-07.1 Security Force Assistance and the ISAF SFA Concept and Implementation Guidance. We also examined key planning documents, such as operational plans and orders, theater commanders' requests for forces, and select advisor team mission briefs and after-action reports. Additionally, we interviewed officials in the United States from the Office of the Secretary of Defense, Department of the Army, Headquarters Marine Corps, as well as officials in Afghanistan from ISAF, ISAF Joint Command, regional commands, and U.S. Army and Marine Corps advisor teams.

To determine the extent to which the Army and Marine Corps have been able to provide SFA advisor teams, we reviewed documents such as theater and combatant commanders' requests for forces that establish personnel requirements for SFA advisor teams and Army and Marine Corps sourcing documents, including execution orders and other manning guidance. We also examined ISAF, ISAF Joint Command, and Army and Marine documents detailing the structure and composition of the SFA advisor teams, including the ISAF SFA Concept and Implementation Guidance, theater commander operational and fragmentary orders, and unit and advisor team briefings. Additionally, in addition to the officials mentioned above, we also interviewed officials in the United States from Army Forces Command, Marine Corps Central Command, 1st Marine Expeditionary Force, U.S. Central Command, officials from Army brigades that provided SFA advisor teams, and U.S. Army and Marine Corps advisor team personnel in the United States and Afghanistan. 


\section{THE QUARTERLY JOURNAL}

To determine the extent to which the Army and Marine Corps have developed programs to train SFA advisor teams for their specific missions in Afghanistan, we reviewed theater commanders' and service training requirements for SFA advisor teams, such as U.S. Central Command theater training requirements, ISAF minimum training requirements for SFA advisor teams, and Army and Marine Corps training requirements for SFA advisor teams. We also examined documents detailing Army and Marine Corps advisor training programs, such as concept briefs and curriculum documents from the 162nd Infantry Training Brigade, the Joint Readiness Training Center, the Marine Corps Advisor Training Group, and Marine Corps Advisor Training Cell. We also reviewed after-action reports and lessons-learned documents from SFA advisor teams.

Additionally, we interviewed officials from the Army 162nd Infantry Training Brigade, Joint Readiness Training Center, 1st Marine Expeditionary Force Advisor Training Cell, Marine Corps Advisor Training Group, and U.S. Army and Marine Corps advisor personnel conducting training in the United States and deployed in Afghanistan, as well as from those organizations mentioned earlier.

We visited or contacted officials from the following organizations in the United States and Afghanistan during our review:

DOD Organizations in the United States

- Office of the Secretary of Defense, Arlington, Virginia

- U.S. Central Command, Tampa, Florida

- U.S. Army

o Department of the Army Headquarters, Arlington, Virginia

o U.S. Army Forces Command, Fort Bragg, North Carolina

o 162nd Infantry Training Brigade, Fort Polk, Louisiana

o Joint Readiness Training Center, Fort Polk, Louisiana

o 101st Airborne Division, Fort Campbell, Kentucky

- U.S. Marine Corps

o Headquarters, Marine Corps, Arlington, Virginia

o Marine Corps Central Command, Tampa, Florida

o 1st Marine Expeditionary Force, including its Advisor Training Cell, Camp Pendleton, California

o Advisor Training Group, Marine Corps Air Ground Combat Center, Twentynine Palms, California

DOD and International Entities in Afghanistan

- North Atlantic Treaty Organization (NATO) entities, including the following:

o ISAF, ISAF Commander's Advisory and Assistance Team, and ISAF Joint Command, Kabul, Afghanistan

o NATO Training Mission-Afghanistan, Kabul, Afghanistan 
o Regional Command headquarters and staff:

- Regional Command-East (Commanded by 1st Infantry Division, U.S. Army), Bagram Air Field, Afghanistan

- Regional Command-South (Commanded by 3rd Infantry Division, U.S. Army), Kandahar Air Field, Afghanistan

- Regional Command-Southwest (Commanded by 1st Marine Expeditionary Force (Fwd), U.S. Marine Corps), Camp Leatherneck, Afghanistan

- U.S. Forces-Afghanistan, Kabul, Afghanistan

- U.S. Army and Marine Corps Units, Personnel, and Advisor Teams deployed in Afghanistan:

o 4th Brigade, 4th Infantry Division, U.S. Army

o 2nd Stryker Brigade, 2nd Infantry Division, U.S. Army

- 162nd Infantry Training Brigade training liaison officers

o 23 SFA advisor teams in Afghanistan, including the following:

- 7 Army advisor teams in Regional Command-East

- 10 Army advisor teams in Regional Command-South

- 5 Marine Corps advisor teams in Regional Command-Southwest

- 1 Army advisor team in Regional Command-West.

As part of this review, we selected an illustrative, non-generalizable sample of deployed U.S. Army and Marine Corps SFA advisor teams in Afghanistan. We worked with theater commands in Afghanistan to identify and meet with a selection of advisor teams that included both Army and Marine Corps advisor teams, advisor teams operating in different regional commands, and advisor teams assigned to various types (e.g., army, police, operational coordination center, etc.) and levels (e.g., corps, brigade, battalion, etc.) of the ANSF. Ultimately, we met with 23 deployed U.S. advisor teams in Afghanistan operating in four different regional commands' areas of operations - 18 Army teams and 5 Marine Corps teams.

We conducted this performance audit from June 2012 to April 2013 in accordance with generally accepted government auditing standards. Those standards require that we plan and perform the audit to obtain sufficient, appropriate evidence to provide a reasonable basis for our findings and conclusions based on our audit objectives. We believe that the evidence obtained provides a reasonable basis for our findings and conclusions based on our audit objectives.

\section{Appendix III: GAO Contact and Staff Acknowledgments}

\section{GAO Contact}

Sharon Pickup, (202) 512-9619 or pickups@gao.gov 


\section{THE QUARTERLY JOURNAL}

Staff Acknowledgments

In addition to the contact named above, James A. Reynolds, Assistant Director; Virginia Chanley; Carole Coffey; Grace Coleman; Mark Dowling; Kasea Hamar; Marcus Oliver; Luis Rodriguez; and Sally Williamson made key contributions to this report.

\section{Related GAO Products}

Building Partner Capacity: Key Practices to Effectively Manage Department of Defense Efforts to Promote Security Cooperation, GAO-13-335T (Washington, D.C.: GAO, February 2013), available at http:/www.gao.gov/products/GAO-13-335T.

Afghanistan: Key Oversight Issues, GAO-13-218SP (Washington, D.C.: GAO, February 2013), available at http://www.gao.gov/products/GAO-13-218SP.

Afghanistan Security: Security Transition, GAO-12-598C (Washington, D.C.: GAO, September 2012).

Observations on U.S. Military Capabilities to Support Transition of Lead Security Responsibility to Afghan National Security Forces, GAO-12-734C (Washington, D.C.: GAO, August 2012).

Afghanistan Security: Long-standing Challenges May Affect Progress and Sustainment of Afghan National Security Forces, GAO-12-951T (Washington, D.C.: GAO, July 2012), available at http://www.gao.gov/products/GAO-12-951T.

Interim Results on U.S.-NATO Efforts to Transition Lead Security Responsibility to Afghan Forces, GAO-12-607C (Washington, D.C.: GAO, May 2012).

Security Force Assistance: Additional Actions Needed to Guide Geographic Combatant Command and Service Efforts, GAO-12-556 (Washington, D.C.: GAO, May 2012), available at http://www.gao.gov/products/GAO-12-556.

Iraq and Afghanistan: Actions Needed to Enhance the Ability of Army Brigades to Support the Advising Mission, GAO-11-760 (Washington, D.C.: GAO, August 2011), available at http://www.gao.gov/products/GAO-11-760. 
SPRING 2013

\section{Bibliography}

Iraq and Afghanistan: Actions Needed to Enhance the Ability of Army Brigades to Support the Advising Mission. Washington, D.C.: GAO, 2011. 